\title{
Uczestnictwo mniejszości narodowych i etnicznych w polskim życiu politycznym po 1989 roku
}

\author{
DOI: $10.19195 / 1643-0328.27 .5$
}

Słowa kluczowe: mniejszości narodowe i etniczne w Polsce, wybory parlamentarne, wybory samorządowe, mniejszość niemiecka na Śląsku Opolskim

\section{Wprowadzenie}

Problematyka udziału mniejszości narodowych i etnicznych w wyborach samorządowych była już kilkakrotnie przedmiotem badań ${ }^{1}$, aczkolwiek zdecydowanie najbogatszy materiał do analiz zawsze dotyczył mniejszości niemieckiej. Kilku autorów analizowało już szczegółową aktywność polityczną mniejszości niemieckiej (dalej: MN) i ich największej organizacji - Towarzystwa Społeczno-Kulturalnego na Śląsku Opolskim (TSKN). Do kanonu publikacji podejmujących ten temat należy od wielu lat monografia Danuty Berlińskiej ${ }^{2}$, a także książki Michała Lisa ${ }^{3}$. Tematyka była też przedmiotem badań Andrzeja Szczepańskiego ${ }^{4}$. Badacze, w szczególności z opolskiego środowiska naukowego, w swoich analizach podejmują również aspekt znaczenia tej społeczności dla polsko-niemieckich stosunków politycznych ${ }^{5}$. Na tym tle interesujące z punktu wi-

1 Zob. na przykład E. Ganowicz, Rywalizacja polityczna mniejszości narodowych w wyborach samorzadowych w Polsce po roku 1989, Opole 2014.

2 D. Berlińska, Mniejszość niemiecka na Ślasku Opolskim w poszukiwaniu tożsamości, Opole 1999.

3 Zob. na przykład M. Lis, Mniejszość niemiecka na Śląsku Opolskim 1989-2014. Z bagażem przeszłości w realiach współczesności, Opole 2016.

4 A. Szczepański, Aktywność społeczno-polityczna mniejszości niemieckiej na Śląsku Opolskim po 1989 roku, Toruń 2013.

5 Zob. na przykład artykuły Aleksandry Trzcielińskiej-Polus: Mniejszość niemiecka w Polsce. Implementacja art.art. 20-22 Traktatu o dobrym sasiedztwie i przyjaznej współpracy z 1991 r., [w:] Przełom i wyzwanie. XX lat polsko-niemieckiego Traktatu o dobrym sąsiedztwie i przyjaznej wspótpracy 1991-2011, red. W.M. Góralski, Warszawa 2011, s. 370-392; eadem, Ewolucja roli mniejszości niemieckiej w Polsce oraz Polonii w Niemczech $w$ stosunkach polsko-niemieckich pod koniec XX i na początku XXI w., „Krakowskie Studia 
dzenia naukowego są dwa - w opinii autora dotychczas niedostatecznie zbadane - obszary działalności MN: sfera pamięci zbiorowej tej społeczności, która rozwija się w cieniu procesów tożsamościowych i komemoracyjnych zachodzących w społeczeństwie niemieckim i polskim, oraz sfera partycypacji wyborczej tej grupy na tle społeczności regionu i kraju ${ }^{6}$. Warto też wskazać dorobek Lecha M. Nijakowskiego, który w swoich badaniach naświetlał specyfikę opolskiej pamięci zbiorowej ${ }^{7}$. W przeglądzie literatury podejmującej temat mniejszości w Polsce, także z punktu widzenia realizacji praw tych grup, należy wspomnieć o pozycjach Grzegorza Janusza ${ }^{8}$, pracach zbiorowych Cezara Trosiaka ${ }^{9}$ i Sławomira Łodzińskiego ${ }^{10}$.

Wydaje się, że kwestia udziału społeczności mniejszościowych w życiu publicznym może uchodzić za miarę dojrzałości demokratycznej społeczeństwa. W kontekście rozważań nad obchodzonymi w 2018 i 2019 roku jubileuszami stulecia polskiej państwowości i trzydziestej rocznicy demokratycznych przemian kwestia ta zasługuje na refleksję naukową uwypuklającą ewolucję form aktywności mniejszości na gruncie politycznym. Celem artykułu jest zatem analiza uczestnictwa mniejszości narodowych i etnicznych w Polsce w życiu publicznym po 1989 roku z punktu widzenia udziału organizacji tych grup w wyborach samorządowych i parlamentarnych.

\section{Odrodzenie i upodmiotowienie mniejszości narodowych i etnicznych w Polsce po 1989 roku}

Rozważania nad uczestnictwem mniejszości narodowych i etnicznych w polskim życiu publicznym III RP warto rozpocząć od konstatacji, iż faktyczną obecność tych grup w życiu publicznym można było odnotować po demokratycznym przełomie. Po zakończeniu powojennego transferu ludności polskie społeczeństwo stało się jednym z najbardziej jednolitych w Europie, udział mniejszości spadł do poziomu około $1 \%^{11}$. Wartość ta jest jednak szacunkiem, ponieważ przed 1989 rokiem GUS odnotował obecność

Międzynarodowe" 2016, nr 2, s. 23-41; eadem, Udział mniejszości niemieckiej w życiu politycznym, [w:] Niemcy, red. L.M. Nijakowski, Warszawa 2016, s. 101-121.

${ }^{6}$ Zob. M. Mazurkiewicz, Partycypacja mniejszości niemieckiej w polskim życiu publicznym po 1989 r. - przypadek Śląka Opolskiego, „Rocznik Ziem Zachodnich” 2017, nr 1, s. 143-164; idem, Kultura pamięci mniejszości niemieckiej na Górnym Śląsku - między trudna przeszłością a wyzwaniami współczesności, „Pogranicze. Polish Borderlands Studies" 6, 2018, nr 3, s. 211-227.

7 Por. L.M. Nijakowski, Domeny symboliczne: konflikty narodowe i etniczne w wymiarze symbolicznym, Warszawa 2006; idem, Polska polityka pamięci: esej socjologiczny, Warszawa 2008.

${ }^{8}$ Zob. na przykład G. Janusz, Ochrona praw mniejszości narodowych w Europie, Lublin 2011.

${ }^{9} \mathrm{Na}$ przykład Między lękiem a nadzieją: dziesięć lat funkcjonowania ustawy o mniejszościach narodowych i etnicznych oraz o języku regionalnym (2005-2015), red. A. Adamczyk, A. Sakson, C. Trosiak, Poznań 2015.

10 Mniejszości narodowe i etniczne w Polsce w świetle Narodowego Spisu Powszechnego z 2011 roku, red. S. Łodziński, K. Warmiński, G. Gudaszewski, Warszawa 2016.

11 O mniejszościach narodowych i etnicznych w II RP zob. między innymi H. Chałupczak, T. Browarek, Mniejszości narodowe w Polsce 1918-1995, Lublin 1998. 
mniejszości tylko w 1946 roku w ramach spisu sumarycznego ${ }^{12}$. Dopiero w 2002 roku założenia metodologiczne spisu powszechnego przewidywały możliwość deklaracji niepolskiej tożsamości narodowej ${ }^{13}$.

Do 1989 roku jednym z elementów polityki negacji obecności innych kultur i osób o zróżnicowanym rysie tożsamościowym w polskim społeczeństwie była antyniemieckośćc $^{14}$. Co oczywiste, miała ona swoje emocjonalne źródła w okresie drugiej wojny światowej. Aczkolwiek już w drugiej połowie lat czterdziestych ubiegłego wieku, jeszcze przed powstaniem dwóch państw niemieckich, antyniemieckość zyskała dodatkowe polityczne tło, uwarunkowane bipolarną rywalizacją. Antyniemieckość miała skomplikowany i zróżnicowany pod względem poznawczym charakter, gdyż miała historycznie i emocjonalnie uzasadnione racje, ale jej polityczny kontekst miał już charakter dwulicowy: byli dobrzy Niemcy z Niemieckiej Republiki Demokratycznej i źli Niemcy z Republiki Federalnej, aczkolwiek od połowy lat siedemdziesiątych coraz wyraźniejszy był rozdźwięk między antyniemieckością polskiego oficjalnego dyskursu a odbiorem społecznym. Od 1975 do 1989 roku sympatia do Niemców wzrosła z poziomu 6\% do 20\%, lecz niechęć do Niemców spadła z poziomu $60 \%$ do $27 \%{ }^{15}$.

Trend ten znalazł również odzwierciedlenie w społecznym odbiorze obecności niemieckości i rodzimych Niemców w polskiej przestrzeni publicznej w czasie demokratycznych przemian. Podczas gdy jeszcze w połowie lat osiemdziesiątych XX wieku 80\% badanych nie wyobrażało sobie, by w szkołach nauczano niemieckiego, a w kościołach odprawiano msze w języku niemieckim, to już na początku kolejnej dekady około 57\% respondentów akceptowało obecność niemieckiego w edukacji i kościele, a szerzej w przestrzeni publicznej ${ }^{16}$.

Na przykładzie genezy i zmiany w społecznym odbiorze zagadnienia obecności i akceptacji Niemców, niemieckiej kultury i języka w przestrzeni publicznej na przełomie lat osiemdziesiątych i dziewięćdziesiątych ubiegłego wieku widać generalne zmiany, jakie zachodziły wówczas w polskim społeczeństwie. Zmieniała się społeczna wrażliwość na zagadnienia narodowościowe, rósł poziom akceptacji dla kwestii obecności i tolerancji mniejszości narodowych w polskim społeczeństwie, akceptacja odmienności miała znaczenie modernizacyjne ${ }^{17}$.

Można przyjąć, że wzrost społecznego poziomu akceptacji pluralistycznego obrazu polskiego społeczeństwa po 1989 roku generowały zmiany prawne. W omawianym kontekście szczególnego znaczenia nabiera uchwalenie 7 kwietnia 1989 roku ustawy Prawo

12 Materiał dotyczący spisu sumarycznego jest dostępny w Internecie, na przykład Powszechny sumaryczny spis ludności $z d n$. 14.II. 1946 r., http://statlibr.stat.gov.pl/F?func=find-b\&find_code=SYS\&request=000047189 (dostęp: 11.11.2018).

13 Materiały na temat wyników Narodowego Spisu Powszechnego Ludności i Mieszkań 2002 zob. https:// stat.gov.pl/cps/rde/xbcr/gus/raport_z_wynikow_nsp_ludnosci_i_mieszkan_2002.pdf (dostęp: 11.11.2018).

14 Zob. na przykład M. Miodek, Niemcy. Publicystyczny obraz w „Pionierze”/,Słowie Polskim” 19451989, Wrocław 2008.

15 P. Madajczyk, D. Berlińska, Polska jako państwo narodowe. Historia i pamięć, Warszawa-Opole 2008, s. 575.

16 Ibidem, s. 574.

17 Ibidem, s. 570. 
o stowarzyszeniach. Dla środowisk mniejszościowych była to szansa na „wyjście z cienia". W rezultacie od 1989 roku samoistnie zaczęły się tworzyć organizacje skupiające osoby o niepolskiej tożsamości narodowej ${ }^{18}$. Badacze zagadnienia zauważają, że najaktywniej z tych możliwości skorzystały środowiska identyfikujące się z niemieckością, tworząc na Górnym Śląsku oraz Warmii i Mazurach kilkadziesiąt podmiotów o profilu społeczno-kulturalnym. W 2008 roku na 172 organizacje pozarządowe pełniące rolę reprezentacji lub podmiotów działających na rzecz mniejszości aż 74, to jest $43 \%$ stanowiły organizacje $\mathrm{MN}^{19}$. Inne mniejszości (Tatarzy, Litwini, Ormianie, Karaimi), mniej liczebne i nietworzące tak licznych skupisk, jak polscy Niemcy, koncentrowały swoje wysyłki samoorganizacyjne na „krzewieniu własnej kultury i języka, opiece nad swoim materialnym dziedzictwem, reprezentowaniu członków wobec władz państwowych i utrzymywaniu zgodnych relacji ze społecznością polską"20.

MN aktywniej i skuteczniej niż inne mniejszości korzystała z możliwości, jakie dawało polskie prawo. W tym kontekście nie można też pominąć innego znaczącego faktu, który bezpośrednio wpływał na aktywność organizacyjną $\mathrm{MN}$ na początku transformacyjnych przemian i w późniejszych latach, ale pośrednio oddziaływał również na sytuację wszystkich obecnych w Polsce mniejszości narodowych i etnicznych. Zagadnienie $\mathrm{MN}$ i dążenie do uznania jej podmiotowości było aktywnie wspierane przez $\mathrm{RFN}^{21}$ zarówno przez rząd federalny, jak i środowiska polityczne, to jest partie polityczne i organizacje ziomkowskie.

Można się spierać, czy włączenie zagadnienia mniejszości narodowych do bilateralnych rozmów polsko-niemieckich na początku lat dziewięćdziesiątych ubiegłego wieku było zaczynem późniejszego rozwoju ustawodawstwa polskiego na rzecz tych społeczności. Rozwiązania dotyczące mniejszości, przyjęte w polsko-niemieckim traktacie z 1991 roku, zostały jednak następnie powielone i włączone do treści bilateralnych traktatów Polski z Czeską i Słowacką Republiką Federacyjną, Ukrainą, Białorusią i Litwą ${ }^{22}$.

Upodmiotowienie mniejszości w umowach bilateralnych, które zostały zawarte przez Polskę z jej sąsiadami w pierwszej połowie lat dziewięćdziesiątych, nie oznaczało jednak, że społeczności te zostały również dostrzeżone przez polskie prawodawstwo. Ustawę o mniejszościach uchwalił dopiero Sejm IV kadencji w 2005 roku. Choć projekty ustawy o mniejszościach narodowych pojawiały się w Sejmie II, III kadencji, to prace nad nimi nie wychodziły poza dyskusję nad definicją mniejszości. Tym bardziej należy podkreślić

18 Warto przypomnieć, że w drugiej połowie lat osiemdziesiątych ubiegłego wieku środowiska mniejszości niemieckiej podejmowały kilkanaście prób legalizacji działalności ich organizacji o profilu społeczno-kulturalnym. Zob. M. Lis, op. cit., s. 62.

19 A. Rykała, Mniejszości narodowe i etniczne w Polsce z perspektywy geografii politycznej, „Acta Universitatis Lodziensis. Folia Geographica Socio-Oeconomica” 2004, nr 17, s. 97-98.

20 Ibidem, s. 96.

21 We wspólnym oświadczeniu przyjętym przez Tadeusza Mazowieckiego i Helmuta Kohla 14 listopada 1989 roku w punkcie 45. znalazło się odniesienie do grup ludności „polskiego względnie niemieckiego pochodzenia”, zamieszkujących oba kraje. Zob. 14 listopada 1989, wspólne oświadczenie Mazowiecki-Kohl (fragmenty), [w:] Polska-Niemcy 1945-2007. Od konfrontacji do wspótpracy i partnerstwa w Europie. Studia i dokumenty, Warszawa 2007, s. 355-361.

22 Treści traktatów bilateralnych dostępne na stronach Internetowego Systemu Aktów Prawnych. 
dojrzałość treści obowiązującej, a opracowanej w latach dziewięćdziesiątych Konstytucji, która w art. 35 gwarantuje osobom należącym do mniejszości wolność i prawo do odrębności ${ }^{23}$. W Sejmie IV kadencji prace nad projektem ustawy o mniejszościach rozpoczęły się w 2002 roku i trwały prawie 3 lata. W tym czasie odbył się pierwszy po 1989 roku spis powszechny ${ }^{24}$ w Polsce, a GUS zdążył przedstawić jego wyniki ${ }^{25}$. 6 stycznia 2005 roku Sejm RP uchwalił przełomowe prawo ${ }^{26}$. Uznano 13 mniejszości: 9 narodowych i 4 etniczne ${ }^{27}$.

Dzięki uchwaleniu ustawy o mniejszościach narodowych i etnicznych i o języku regionalnym udało się w Polsce stworzyć system ochrony i wsparcia tych społeczności, który spełnia nie tylko europejskie, lecz także światowe standardy. Z punktu widzenia polskiego prawodawstwa zatem mniejszości mają pełną możliwość do zachowania, kultywowania i rozwoju własnej odrębności. Można nawet powiedzieć, że głównie od inicjatywy i aktywności mniejszości zależy, w jaki sposób mogą korzystać z prawnie nadanej im podmiotowości. Instytucje państwowe, na czele z Ministerstwem Spraw Wewnętrznych i Administracji będącym organem właściwym do spraw mniejszości, kształtują jakość polityki na rzecz mniejszości, a co za tym idzie - praktyczne możliwości wykorzystywania szans, które daje polskie prawo. Nie jest zaskoczeniem, że zdecydowana większość organizacji mniejszościowych jest zależna od systemu dotacyjnego MSWiA ${ }^{28}$.

\section{Uczestnictwo mniejszości narodowych i etnicznych w polskim życiu politycznym}

Jak zauważa Ewa Ganowicz, mniejszości narodowe są podmiotami w rywalizacji politycznej na szczeblu centralnym i lokalnym ${ }^{29}$. MN była też pierwszą mniejszością narodową w Polsce, która zaznaczyła swoją obecność w wymiarze politycznym jeszcze przed wyborami samorządowymi z 1990 roku i parlamentarnymi z 1991 roku. Pierwszymi wyborami III RP, które miały kontekst etniczny, były wybory uzupełniające do Senatu, przeprowadzone w województwie opolskim na początku 1990 roku. Powodem zarzą-

23 S. Łodziński, Wyrównanie czy uprzywilejowanie. Spory dotyczace projektu ustawy o ochronie mniejszości narodowych (1989-2005), Warszawa 2005, s. 3.

${ }^{24} \mathrm{O}$ wynikach spisu zob. także na stronach internetowych Głównego Urzędu Statystycznego: https:// stat.gov.pl/cps/rde/xbcr/gus/raport_z_wynikow_nsp_ludnosci_i_mieszkan_2002.pdf (dostęp: 11.11.2018).

25 O spisie z 2002 roku i jego wynikach powstało już wiele prac, nie sposób tu pominąć opracowań Kazimierza Szczygielskiego, który w swoich badaniach skupiał się na aspektach etnicznych uzyskanych danych. Por. idem, Mniejszości narodowe i etniczne w województwie opolskim a język niepolski: w świetle ustaleń Narodowego Spisu Powszechnego 2002 r., „Śląsk Opolski” 15, 2005, nr 3, s. 5-12; idem, Geografia mniejszości narodowych i etnicznych w Polsce: ujęcie ilościowe, Opole 2006.

26 Tekst ustawy dostępny na stronie http://prawo.sejm.gov.pl/isap.nsf/DocDetails.xsp?id=WDU2005 0170141 (dostęp: 11.11.2018).

27 Mniejszości narodowe: niemiecka, rosyjska, litewska, białoruska, ukraińska, słowacka, czeska, żydowska, ormiańska. Mniejszości etniczne: romska, tatarska, łemkowska, karaimska.

${ }^{28}$ Więcej o zasadach przyznawania dotacji na realizację w 2018 roku zadań mających na celu ochronę, zachowanie i rozwój tożsamości kulturowej mniejszości narodowych i etnicznych oraz zachowanie i rozwój języka regionalnego zob. http://mniejszosci.narodowe.mswia.gov.pl/mne/dotacje (dostęp: 11.11.2018).

29 E. Ganowicz, op. cit., s. 152. 
dzenia wyborów uzupełniających była śmierć Edmunda J. Osmańczyka, który reprezentował okręg opolski w Senacie I kadencji. Pierwszą turę tych wyborów, przy frekwencji wynoszącej 31,4\%, wygrał Henryk Kroll, już wtedy znany działacz MN. Fakt ten zmobilizował wyborców obu opcji — w drugiej turze frekwencja wyniosła już bowiem 54,8\%. H. Kroll uzyskał wtedy 125,5 tys. głosów, jego kontrkandydatka Dorota Simonides 258 tys. ${ }^{30}$. Druga tura $\mathrm{w}$ wymiarze społeczno-medialnym zyskała etniczny i plebiscytarny charakter, elektorat niemiecki wzrósł o prawie $50 \%$, a polski o $100 \%{ }^{31}$.

Wzmianka na temat tych wyborów jest ważna $\mathrm{z}$ wielu powodów. Dla MN były to pierwsze i zarazem najważniejsze wybory po 1989 roku - ukazały potencjał politycznej mobilizacji społeczności, ale jednocześnie był to jej maksymalny poziom. Po wyborach uzupełniających do Senatu w 1990 roku żaden z kandydatów mniejszości nie uzyskał tak wysokiego wyniku, jak H. Kroll.

Rezultat wyborów, chociaż przegranych, zmobilizował i skonsolidował środowisko MN. Miało to swoje przełożenie w pierwszych wolnych wyborach samorządowych, które odbyły się w maju tego samego roku. MN uzyskała w nich 380 na 1440 możliwych do obsadzenia mandatów. W 25 gminach MN uzyskała bezwzględną większość, 25 radnych weszło też w skład Sejmiku Samorządowego Województwa Opolskiego ${ }^{32}$.

Aktywnie w procesach transformacji systemowej uczestniczyli też Białorusini, których entuzjazm związany z demokratyzacją przyczynił się do założenia już w 1989 roku Białoruskiego Komitetu Wyborczego ${ }^{33}$. Również im udało się zmobilizować swój docelowy etniczny elektorat. W wyniku wyborów samorządowych z 1990 roku uzyskali 142 mandaty radnych gmin i miast ${ }^{34}$. Inne mniejszości natomiast nie podjęły inicjatywy powołania własnych etnicznych komitetów wyborczych.

Pierwsze wybory samorządowe miały dla zagadnienia uczestnictwa mniejszości w życiu politycznym w Polsce szczególne znaczenie. Wyznaczyły MN zasięg terytorialny ich politycznego wpływu, który do dziś pozostał w zasadzie niezmienny. Mniejszości białoruskiej natomiast wyniki wyborów samorządowych ukazały potencjał polityczny tkwiący w tym środowisku, z którego jednak w kolejnych latach - na skutek wewnętrznych podziałów i przesunięć sympatii politycznych elektoratu — nie skorzystano w sposób efektywny.

Ważnym rozdziałem $\mathrm{w}$ historii udziału mniejszości w polskim życiu politycznych są wybory parlamentarne z października 1991 roku. Mniejszości utworzyły wtedy pięć komitetów wyborczych (dwa Białorusini, dwa Niemcy, jeden natomiast - Wyborczy Blok Mniejszości - pełnił rolę listy ogólnopolskiej). Rezultat wyborów pokazał, że tylko mniejszość niemiecka miała na tyle duży potencjał mobilizacji politycznej, by uzyskać trwałe miejsce w parlamencie. Na 460 posłów 10 było przedstawicielami mniejszości (7 mandatów uzyskała MN, 2 - Wyborczy Blok Mniejszości, 1 - mniejszość białoruska) ${ }^{35}$.

${ }^{30}$ M. Lis, op. cit., s. 76-77.

31 M. Mazurkiewicz, Partycypacja mniejszości niemieckiej..., s. 153.

32 D. Berlińska, op. cit., s. 219.

33 A. Chodubski, Wyzwania wyborcze, mniejszości narodowych i etnicznych w Polsce, [w:] Mniejszości $w$ wyborach. Wybory mniejszości. Z badań nad partycypacją polityczna mniejszości narodowych i etnicznych, red. J. Mieczkowski, Wydawnictwo Naukowe Uniwersytetu Szczecińskiego, Szczecin 2017, s. 18.

${ }^{34}$ E. Ganowicz, op. cit., s. 182.

35 Ibidem, s. 156. 
W kolejnych kadencjach liczba przedstawicieli mniejszości była wyraźnie niższa. W wyborach z 1993 roku komitety i partie polityczne bowiem rywalizowały już w innych uwarunkowaniach ordynacji wyborczej. Wprowadzone progi wyborcze 5\% dla komitetów wyborczych, $8 \%$ dla komitetów koalicyjnych oraz 7\% dla listy ogólnokrajowej skonsolidowały polską scenę polityczną. Małe, regionalne komitety wyborcze, które mogły pełnić rolę reprezentacji mniejszości, cechowały się zbyt niskim potencjałem wyborczym, by móc rywalizować z ugrupowaniami ogólnopolskimi. W tej kwestii MN miała wyraźną przewagę nad innymi mniejszościami, a w województwie opolskim nawet nad czołowymi partiami politycznymi. Sieć organizacyjna MN, obejmująca poziom sołectw, gmin, powiatów (po 1999 roku) i województwa ${ }^{36}$, była doskonałą bazą społeczną i polityczną do ugruntowania i utrzymania znaczenia politycznego w regionie, jeśli chodzi o wybory zarówno samorządowe, jak i parlamentarne.

Po 1993 roku w ławach sejmowych zasiadali wprawdzie przedstawiciele mniejszości białoruskiej i ukraińskiej, ale w sensie politycznym reprezentowali ogólnopolskie komitety wyborcze. Jeśli zaś chodzi o reprezentację społeczności mniejszościowych w Senacie $\mathrm{RP}$, to uzyskanie mandatu senatora okazywało się o wiele trudniejsze niż mandatu posła. Obowiązująca w wyborach do izby wyższej ordynacja większościowa była poważnym ograniczeniem potencjału wyborczego kandydatów mniejszości. MN udało się wprowadzić swojego reprezentanta do Senatu tylko dwukrotnie — w 1991 i 1993 roku: przedstawiciel mniejszości ormiańskiej w Senacie VII i VIII kadencji został wybrany z ramienia ogólnopolskiego komitetu wyborczego.

Tabela 1. Liczba przedstawicieli mniejszości narodowych w Parlamencie RP w latach 1991-2018 (w nawiasie podano liczbę reprezentantów $\mathrm{MN}$ )

\begin{tabular}{c|c|c|l}
\hline Kadencja & $\begin{array}{c}\text { Liczba przedstawicieli } \\
\text { mniejszości w Sejmie RP }\end{array}$ & $\begin{array}{c}\text { Liczba przedstawicieli } \\
\text { mniejszości w Senacie RP }\end{array}$ & $\begin{array}{l}\text { Mniejszości reprezentowa- } \\
\text { ne w parlamencie }\end{array}$ \\
\hline $1991-1993$ & $10(7)$ & $1(1)$ & niemiecka, białoruska \\
\hline $1993-1997$ & $4(4)$ & $1(1)$ & niemiecka \\
\hline $1997-2001$ & $4(2)$ & 0 & niemiecka, białoruska \\
\hline $2001-2005$ & $5(2)$ & 0 & $\begin{array}{l}\text { niemiecka, ukraińska, } \\
\text { białoruska, }\end{array}$ \\
\hline $2005-2007$ & $4(2)$ & 0 & $\begin{array}{l}\text { niemiecka, ukraińska, } \\
\text { białoruska, }\end{array}$ \\
\hline $2007-2011$ & $3(1)$ & 1 & $\begin{array}{l}\text { niemiecka, ukraińska, } \\
\text { białoruska, ormiańska }\end{array}$ \\
\hline $2011-2015$ & $3(1)$ & 1 & $\begin{array}{l}\text { niemiecka, ukraińska, } \\
\text { białoruska, ormiańska }\end{array}$ \\
\hline $2015-2019$ & $1(1)$ & 0 & niemiecka \\
\hline
\end{tabular}

Źródło: opracowanie własne na podstawie E. Ganowicz, op. cit., s. 152-170; J. Mieczkowski, op. cit., s. 32-34; http:// mniejszosci.narodowe.mswia.gov.pl/mne/mniejszosci/charakterystyka-mniejs/6480, Charakterystyka-mniejszosci-naro dowych-i-etnicznych-w-Polsce.html\#niemcy (dostęp: 11.11.2018).

36 O strukturze organizacyjnej Towarzystwa Społeczno-Kulturalnego Niemców na Śląsku Opolskim zob. http://skgd.pl/o-nas/o-organizacji/struktura/ (dostęp: 11.11.2018). 
Tabela 2. Wyniki mniejszości niemieckiej w wyborach do Sejmu RP w latach 1991-2018

\begin{tabular}{c|c|c}
\hline Kadencja & $\begin{array}{c}\text { Liczba głosów uzyskanych } \\
\text { przez przedstawicieli MN }\end{array}$ & $\begin{array}{c}\text { Liczba mandatów } \\
\text { w Sejmie RP }\end{array}$ \\
\hline $1991-1993$ & 132059 & 7 \\
\hline $1993-1997$ & 60770 & 4 \\
\hline $1997-2001$ & 51027 & 3 \\
\hline $2001-2005$ & 47230 & 2 \\
\hline $2005-2007$ & 34469 & 2 \\
\hline $2007-2011$ & 32462 & 1 \\
\hline $2011-2015$ & 28014 & 1 \\
\hline $2015-2018$ & 27530 & 1 \\
\hline
\end{tabular}

Źródło: opracowanie własne na podstawie D. Berlińska, op. cit., s. 221; http://www.pkw.gov.pl.

Aktywność polityczna mniejszości jest bardziej widoczna na szczeblu samorządowym, ale też niejednolita. W wyborach samorządowych z 2018 roku po raz ósmy z rzędu wzięła udział MN, wystawiając swój komitet wyborczy (Komitet Wyborczy Mniejszość Niemiecka) ${ }^{37}$. MN to jedyna w Polsce mniejszość narodowa, która regularnie uczestniczy w wyborach. Nie znaczy to jednak, że spośród mniejszości tylko jej przedstawiciele czynnie korzystają z prawa wyborczego (w wyborach parlamentarnych z 2001 roku i samorządowych z 2006 roku swoje komitety rejestrowali również Białorusini ${ }^{38}$ ). Przedstawiciele pozostałych grup w innych regionach kraju także zdobywali mandaty na poziomie gmin, powiatów czy sejmiku, aczkolwiek tylko opolscy Niemcy wystawiali do tego celu własny komitet wyborczy ${ }^{39}$, który również w nazwie wskazywał, że kandydaci komitetu reprezentują tę określoną grupę społeczną. Podobna sytuacja miała miejsce już we wcześniejszych latach ${ }^{40}$. Przeprowadzone analizy aktywności politycznej tych środowisk wskazują, że w 2010 i 2014 roku z biernego prawa wyborczego skorzystali przed-

37 https://wybory2018.pkw.gov.pl/pl/delegatury/komisarz-wyborczy-w-opolu-i/komitet-wyborczywyborcow-mniejszosc-niemiecka-4625/160000\#candidates_stat (dostęp: 11.11.2018).

38 E. Ganowicz, op. cit., s. 154-189.

39 W gminie Puńsk w województwie podlaskim, gdzie według danych Narodowego Spisu Powszechnego Ludności i Mieszkań z 2011 roku ponad 75\% mieszkańców przyznaje się do pochodzenia litewskiego, nazwy komitetów wyborczych, odgrywających główne role na lokalnej scenie politycznej, nawiązują do kwestii przedsiębiorczości i rozwoju gminy (Komitet Wyborczy Wyborców Przedsiębiorcza Gmina Puńsk, 13 na 15 mandatów w 2018 roku). Podobnie rzecz się ma w wypadku gminy Czyże (województwo podlaskie, powiat hajnowski), gdzie według danych spisowych aż 76,5\% mieszkańców przyznaje się do białoruskiej narodowości, główną reprezentacją mieszkańców jest Komitet Wyborczy Wyborców Nasza Gmina Czyże, który zdobył 12 na 15 mandatów. Dane za: http://mniejszosci.narodowe.mswia.gov.pl/mne/mniejszosci/charakterystyka-mniejs/6480,Charakterystyka-mniejszosci-narodowych-i-etnicznych-w-Polsce.html\#litwini; https://wybory2018.pkw.gov.pl/pl/geografia/200504\#results_elect_council (dostęp: 11.11.2018).

40 Szerzej zob. J. Mieczkowski, Partycypacja polityczna mniejszości narodowych i etnicznych w Polsce. Kilka uwag z perspektywy wyborów samorządowych 2014 roku, [w]: Mniejszości w wyborach. Wybory mniej- 
stawiciele ośmiu społeczności mniejszościowych. W organach uchwałodawczych różnych szczebli zasiedli reprezentanci mniejszości: białoruskiej, litewskiej, łemkowskiej, niemieckiej, ormiańskiej, słowackiej, ukraińskiej i żydowskiej ${ }^{41}$.

Najbardziej zorganizowany charakter uczestnictwa w wyborach mieli jednak przedstawiciele trzech mniejszości: Białorusini, Litwini i oczywiście Niemcy. Wydaje się, że głównym powodem jest to, że tylko te mniejszości tworzą zwarte skupiska. W wypadku Białorusinów są to powiaty: hajnowski, bielski, siemiatycki i białostocki; Litwinów — powiat sejneński w województwie podlaskim, a Niemców - wschodni i południowo-wschodni obszar województwa opolskiego. Należy dodać, że większe skupiska MN występują również na terenie powiatów gliwickiego, raciborskiego i lublinieckiego w województwie śląskim, ale ich aktywność polityczna jest znikoma.

Udział mniejszości w wyborach, oprócz Niemców, nie ma kontekstu etnicznego startują one z lokalnych lub ogólnokrajowych komitetów wyborczych ${ }^{42}$. MN, co już wielokrotnie podkreślano, jako jedyna z tych społeczności wystawia własny komitet. W wyborach do Sejmu RP MN korzysta z zapisów Kodeksu Wyborczego, który organizacje mniejszościowe zwalnia z wymogu przekroczenia 5\% progu wyborczego w skali $\mathrm{kraju}^{43}$. W lutym 2018 roku działacze MN powołali partię polityczną pod nazwą Regionalna. Mniejszość z Większością ${ }^{44}$, której pierwszy start w wyborach możliwy jest w 2019 roku $^{45}$.

Warto w tym miejscu porównać wyniki, jakie uzyskiwały komitety MN w wyborach do Sejmu RP po 1997 roku, z wynikami wyborów do Sejmiku Województwa Opolskiego po 1998 roku. Wybory samorządowe miały dla elektoratu mniejszości większe znaczenie, co więcej - w wypadku wyborów do Sejmu od lat dziewięćdziesiątych odnotowuje się sukcesywny spadek poparcia dla kandydatów MN. Inaczej sytuacja przedstawia się w wypadku wyborów do Sejmiku. Od 2002 roku poparcie mniejszości się zmienia, a krzywa wyników wyborczych uzyskiwanych przez MN może przypominać sinusoidę. Innym ciekawym zjawiskiem jest stopniowy (a może i nieuchronny) spadek znaczenia politycznego w regionie.

szości. Z badań nad partycypacją polityczna mniejszości narodowych i etnicznych, red. J. Mieczkowski, Szczecin 2017, s. 32-34.

${ }^{41} \mathrm{Ibidem}$, s. 32-34. Zob. też http://mniejszosci.narodowe.mswia.gov.pl/mne/mniejszosci/charakterystyka-mniejs/6480,Charakterystyka-mniejszosci-narodowych-i-etnicznych-w-Polsce.html (dostęp: 11.11.2018).

${ }^{42}$ Za przykład tej sytuacji weźmy przedstawicieli mniejszości, którzy zasiadali w Sejmie VII i Senacie VIII kadencji w latach 2011-2015. W Parlamencie mieliśmy przedstawicieli 4 mniejszości: białoruskiej (wybranego z ramienia SLD), ukraińskiej (wybranego z ramienia PO), ormiańskiej (wybranego z ramienia PO) i niemieckiej, który jako jedyny członek społeczności mniejszościowej uzyskał mandat parlamentarzysty $\mathrm{z}$ ramienia organizacji własnego środowiska.

43 Wyciąg z Kodeksu wyborczego, zob. http://mniejszosci.narodowe.mswia.gov.pl/mne/prawo/zapisy-z-konstytucji-r/6454,Kodeks-wyborczy.html (dostęp: 11.11.2018).

44 https://pkw.gov.pl/322_Wykaz_partii_politycznych (dostęp: 11.11.2018).

45 Poseł mniejszości niemieckiej Ryszard Galla tak komentował powody powołania partii politycznej: „Zrobiliśmy to na wszelki wypadek, ponieważ mówiło się o tym, że zgodnie z nową ordynacją wyborczą w wyborach będą mogły startować tylko partie. Chcemy być taką partią regionalną. Wniosek złożyliśmy już kilka miesięcy temu. Potrzebne było uszczegółowienie kilku kwestii. Tak więc teraz czekamy praktycznie na decyzję o wpisaniu do rejestru”. Cyt. za: K. Śnigórski, Regionalna Mniejszość z Większościa - tak ma się nazywać partia Mniejszości Niemieckiej. Wniosek jest już w sądzie, http://radio.opole.pl/100,220443, regionalnamniejszosc-z-wiekszoscia-tak-ma-sie-n\&s=6\&si=6\&sp=6 (dostęp: 11.11.2018). 
W wyborach samorządowych z 2018 roku MN uzyskała 207 mandatów w radach gmin, $45 \mathrm{w}$ radach powiatów, 5 mandatów w Sejmiku, w 2014 roku było to odpowiednio: 259 (gminy), 45 (powiaty), 7 (sejmik), a w 2010 roku 268 (gminy), 49 (powiaty), 6 (sejmik). Widać zatem, że znaczenie polityczne $\mathrm{MN}$ w regionie ma trend spadkowy. Ta konstatacja opiera się jednak na spojrzeniu na wyniki wyborcze MN z poziomu regionu. Są gminy w województwie opolskim, w których to MN jest główną siłą polityczną, na tyle dominującą i akceptowaną przez większość społeczności lokalnej, że w najbliższej przyszłości nie należy się spodziewać zmian w tym zakresie. Są to zarazem gminy, w których od lat konkurencyjne wybory do rady gminy odbywają się tylko w niektórych obwodach. W pozostałych kandydaci MN byli jedynymi ubiegającymi się o mandat, a z punktu widzenia ordynacji wyborczej w takich obwodach głosowania się nie przeprowadza ${ }^{46}$.

Duże znaczenie dla politycznej przyszłości MN w województwie opolskim będą miały nadchodzące wybory parlamentarne. Jeśli spadkowy trend poparcia w wyborach do Sejmu RP utrzyma się, istnieje możliwość, że MN może stracić mandat. Może to wpłynąć na zmianę strategii politycznej ich głównej organizacji.

Tabela 3. Wyniki mniejszości niemieckiej w wyborach do Sejmiku Województwa Opolskiego w latach $1998-2018^{47}$.

\begin{tabular}{c|c|c}
\hline Kadencja & $\begin{array}{c}\text { Liczba głosów uzyskanych } \\
\text { przez komitet wyborczy MN }\end{array}$ & Liczba mandatów \\
\hline $1998-2002$ & 67921 & 13 \\
\hline $2002-2006$ & 54385 & 7 \\
\hline $2006-2010$ & 49131 & 7 \\
\hline $2010-2014$ & 53670 & 6 \\
\hline $2014-2018$ & 41889 & 7 \\
\hline $2018-2023$ & 52431 & 5 \\
\hline
\end{tabular}

Źródło: opracowanie własne na podstawie http://www.pkw.gov.pl.

Pozostałe mniejszości podążają już inną drogą, swoją etniczną odrębność kierunkują głównie ku pielęgnowaniu dziedzictwa przeszłości i kwestiom związanym z zachowaniem oraz rozwojem własnej tożsamości. Działalność polityczną natomiast łączą pragmatycznie z pracą na rzecz rozwoju własnych społeczności lokalnych. Komitety wyborcze, które są przez przedstawicieli mniejszości tworzone lub współtworzone, nie cechują się etnicznością.

46 Jaskrawym przykładem tego zjawiska jest gmina Leśnica (powiat strzelecki), w której w 2018 roku cały skład rady gminy został wyłoniony jeszcze przed wyborami (13 mandatów zdobyli kandydaci MN), a urzędujący burmistrz nie miał kontrkandydata, w gminie Chrząstowice natomiast w głosowanie odbyło się tylko w jednym obwodzie (13 mandatów zdobyli kandydaci MN), podobnie było w gminie Walce (13 mandatów zdobyli kandydaci MN).

47 W kadencji 1998-2002 skład Sejmiku Województwa Opolskiego liczył 45 mandatów, od 2002 roku w Sejmiku zasiada 30 radnych. 


\section{Podsumowanie}

Udział mniejszości w polskim życiu politycznym po 1989 roku jest jednym z osiągnięć III RP. Udało się bowiem stworzyć warunki do upodmiotowienia i pełnego uczestnictwa społeczności mniejszościowych we wszystkich aspektach życia społeczno-politycznego. Prześledzenie historii uczestnictwa mniejszości w wyborach samorządowych i parlamentarnych po 1990 roku uzmysławia jednak, że historia ta jest zdominowana przez MN. Nie znaczy to jednak, że inne mniejszości nie uczestniczyły w rywalizacji politycznej na poziomie lokalnym, regionalnym czy krajowym, udział ich był jednak w porównaniu z MN wyraźnie skromniejszy. MN, jako najbardziej liczebna i najlepiej zorganizowana mniejszość narodowa w Polsce, ma ugruntowaną pozycję w życiu społeczno-politycznym województwa opolskiego. Przemiany demograficzne i procesy związane z fluktuacją poparcia wyborczego mogą jednak tę pozycję osłabiać, a symptomy wskazujące na to zagrożenie są widoczne już od lat. Udział w życiu politycznym innych mniejszości ma wymiar głównie samorządowy, chociaż społeczności te nie decydują się na wystawianie własnych, etnicznych komitetów wyborczych. Być może ich tożsamościowa odrębność nie wymaga potwierdzenia w ich aktywności i preferencjach politycznych.

\section{Bibliografia}

14 listopada 1989, wspólne oświadczenie Mazowiecki-Kohl (fragmenty), [w:] Polska-Niemcy 1945-2007. Od konfrontacji do wspótpracy i partnerstwa w Europie. Studia i dokumenty, Polski Instytut Spraw Międzynarodowych, Warszawa 2007, s. 355-361.

Berlińska D., Mniejszość niemiecka na Śląsku Opolskim w poszukiwaniu tożsamości, Państwowy Instytut Naukowy — Instytut Śląski w Opolu, Opole 1999.

Chałupczak H., Browarek T., Mniejszości narodowe w Polsce 1918-1995, Wydawnictwo Uniwersytetu Marii Curie-Skłodowskiej, Lublin 1998.

Chodubski A., Wyzwania wyborcze, mniejszości narodowych i etnicznych w Polsce, [w:] Mniejszości w wyborach. Wybory mniejszości. Z badań nad partycypacja polityczna mniejszości narodowych i etnicznych, red. J. Mieczkowski, Wydawnictwo Naukowe Uniwersytetu Szczecińskiego, Szczecin 2017, s. 13-26.

Ganowicz E., Rywalizacja polityczna mniejszości narodowych w wyborach samorzadowych w Polsce po roku 1989, Wydawnictwo Uniwersytetu Opolskiego, Opole 2014.

http://mniejszosci.narodowe.mswia.gov.pl - strona internetowa Ministerstwa Spraw Wewnętrznych i Administracji, serwis na temat mniejszości narodowych i etnicznych w Polsce.

http://prawo.sejm.gov.pl - strona internetowa Sejmu RP.

http://radio.opole.pl - strona internetowa Radia Opole.

http://skgd.pl/ — strona internetowa Towarzystwa Społeczno-Kulturalnego Niemców na Śląsku Opolskim. https://stat.gov.pl/ — strona internetowa Głównego Urzędu Statystycznego.

https://wybory2018.pkw.gov.pl - strona internetowa Państwowej Komisji Wyborczej na temat wyborów samorządowych z 2018 roku.

Janusz G., Ochrona praw mniejszości narodowych w Europie, Wydawnictwo Uniwersytetu Marie Curie-Skłodowskiej, Lublin 2011.

Lis M., Mniejszość niemiecka na Śląsu Opolskim 1989-2014. Z bagażem przeszłości w realiach współczesności, Państwowy Instytut Naukowy — Instytut Śląski w Opolu, Opole 2016. 
Łodziński S., Wyrównanie czy uprzywilejowanie. Spory dotyczące projektu ustawy o ochronie mniejszości narodowych (1989-2005), Raport nr 232, Kancelaria Sejmu. Biuro Studiów i Ekspertyz, Warszawa 2005.

Madajczyk P., Berlińska D., Polska jako państwo narodowe. Historia i pamięć, Instytut Studiów Politycznych Polskiej Akademii Nauk, Państwowy Instytut Naukowy — Instytut Śląski, Warszawa-Opole 2008.

Mazurkiewicz M., Kultura pamięci mniejszości niemieckiej na Górnym Śląsku - między trudna przeszłością a wyzwaniami współczesności, „Pogranicze. Polish Borderlands Studies” 6, 2018, nr 3, s. 211-227.

Mazurkiewicz M., Partycypacja mniejszości niemieckiej w polskim życiu publicznym po 1989 r. - przypadek Ślaska Opolskiego, „Rocznik Ziem Zachodnich” 2017, s. 143-164.

Mieczkowski J., Partycypacja polityczna mniejszości narodowych i etnicznych w Polsce. Kilka uwag z perspektywy wyborów samorządowych 2014 roku, [w:] Mniejszości w wyborach. Wybory mniejszości. Z badań nad partycypacja polityczna mniejszości narodowych i etnicznych, red. J. Mieczkowski, Wydawnictwo Naukowe Uniwersytetu Szczecińskiego, Szczecin 2017, s. 27-42.

Między lękiem a nadzieją: dziesięć lat funkcjonowania ustawy o mniejszościach narodowych i etnicznych oraz o języku regionalnym (2005-2015), red. A. Adamczyk, A. Sakson, C. Trosiak, Wydawnictwo Naukowe Wydziału Nauk Politycznych i Dziennikarstwa Uniwersytetu im. Adama Mickiewicza, Poznań 2015.

Miodek M., Niemcy. Publicystyczny obraz w „Pionierze”/,Słowie Polskim” 1945-1989, Oficyna Wydawnicza Atut - Wrocławskie Wydawnictwo Oświatowe, Wrocław 2008.

Mniejszości narodowe i etniczne w Polsce w świetle Narodowego Spisu Powszechnego z 2011 roku, red. S. Łodziński, K. Warmiński, G. Gudaszewski, Wydawnictwo Naukowe Scholar, Warszawa 2016.

Nijakowski L.M., Domeny symboliczne: konflikty narodowe i etniczne w wymiarze symbolicznym, Wydawnictwo Naukowe Scholar, Warszawa 2006.

Nijakowski L.M., Polska polityka pamięci: esej socjologiczny, Wydawnictwa Akademickie i Profesjonalne, Warszawa 2008.

Nijakowski L.M., Szteliga J., Informator o spornych pomnikach niemieckich na Ślasku Opolskim, Opolskie Stowarzyszenie na rzecz Rozwoju Myśli Lewicowej, Samorządności Lokalnej Demokratycznego Państwa Prawa „Dla Przyszłości”, Opole 2005.

pkw.gov.pl — strona internetowa Państwowej Komisji Wyborczej.

Rykała A., Mniejszości narodowe i etniczne w Polsce z perspektywy geografii politycznej, „Acta Universitatis Lodziensis. Folia Geographica Socio-Oeconomica” 2004, nr 17, s. 63-110.

Szczepański A., Aktywność społeczno-polityczna mniejszości niemieckiej na Śląsku Opolskim po 1989 roku, Wydawnictwo Adam Marszałek, Toruń 2013.

Szczygielski K., Geografia mniejszości narodowych i etnicznych w Polsce: ujęcie ilościowe, Opole 2006.

Szczygielski K., Mniejszości narodowe i etniczne w województwie opolskim a język niepolski: w świetle ustaleń Narodowego Spisu Powszechnego 2002 r., „Śląsk Opolski” 15, 2005, nr 3, s. 5-12.

Śnigórski K., Regionalna Mniejszość z Większościa - tak ma się nazywać partia Mniejszości Niemieckiej. Wniosek jest już w sądzie, http://radio.opole.pl/100,220443, regionalna-mniejszosc-z-wiekszoscia-takma-sie-n\&s=6\&si=6\&sp=.

Trzcielińska-Polus A., Ewolucja roli mniejszości niemieckiej w Polsce oraz Polonii w Niemczech $w$ stosunkach polsko-niemieckich pod koniec XX i na początku XXI w., „Krakowskie Studia Międzynarodowe” 2016, nr 2, s. 23-41.

Trzcielińska-Polus A., Mniejszość niemiecka w Polsce. Implementacja art. art. 20-22 Traktatu o dobrym sqsiedztwie i przyjaznej wspótpracy z 1991 r., [w:] Przełom i wyzwanie. XX lat polsko-niemieckiego Traktatu o dobrym sąsiedztwie i przyjaznej wspótpracy 1991-2011, red. W.M. Góralski, Dom Wydawniczy Elipsa, Warszawa 2011, s. 370-392.

Trzcielińska-Polus A., Udział mniejszości niemieckiej w życiu politycznym, [w:] Niemcy, red. L.M. Nijakowski, Kancelaria Sejmu. Wydawnictwo Sejmowe, Warszawa 2016, s. 101-121. 


\section{Participation of national and ethnic minorities in Polish political life after 1989}

Keywords: national and ethnic minorities in Poland, parliamentary elections, local elections, German minority in Opole Silesia

Summary

The participation of national and ethnic minorities in Polish political life after 1989 is one of the achievements of democratic Poland. Tracing the history of minority participation in local and parliamentary elections after 1990 makes it clear that this history is dominated by the German minority. However, this does not mean that other minorities did not participate in political competition at the local, regional or national level, but rather that their participation was clearly more modest compared to the German minority. Participation in the political life of other minorities has mainly a local dimension, although these communities do not choose to participate in their own ethnic election committees. Perhaps their identity does not require confirmation in their political activities and preferences. 